\title{
JNPH
}

Volume 7 No. 1 (April 2019)

(C) The Author(s) 2019

\section{HUBUNGAN TINGKAT PENGETAHUAN DAN SIKAP DENGAN PELAKSANAAN SANITASI TOTAL BERBASIS MASYARAKAT (STBM) PILAR PERTAMA DI WILAYAH KERJA UPTD PUSKESMAS PERAWATAN RATU AGUNG KELURAHAN PEMATANG GUBERNUR KOTA BENGKULU}

\author{
RELATIONSHIP OF KNOWLEDGE AND ATTITUDE LEVEL WITH THE \\ IMPLEMENTATION OF THE FIRST COMMUNITY-BASED TOTAL SANITATION \\ (STBM) IN THE WORKING AREA OF UPTD PUSKESMAS PERAWATAN RATU \\ AGUNG KELURAHAN PEMATANG GUBERNUR, BENGKULU CITY
}

\author{
ANDRIANA MARWANTO, NETRIANIS, MUALIM \\ POLITEKNIK KESEHATAN KEMENKES BENGKULU, \\ JURUSAN KESEHATAN LINGKUNGAN \\ Email: andrian.marwanto@gmail.com
}

\begin{abstract}
ABSTRAK
Latar belakang: Pelaksanaan program STBM dimulai dari pilar pertama yaitu Stop BABs yang merupakan pintu masuk sanitasi total dan merupakan upaya memutuskan rantai kontaminasi kotoran manusia terhadap air baku minum, makan dan lainnya. STBM diharapkan dapat merubah perilaku kelompok masyarakat dalam upaya memperbaiki keadaan sanitasi lingkungan mereka, sehingga tercapai kondisi Open Defecation Free (ODF). faktor penentu perilaku terdiri dari faktor predisposisi (pengetahuan, tindakan), faktor pemungkin (sosialisasi, saranaprasarana), faktor penguat (dukungan keluarga dan petugas kesehatan). Penelitian ini bertujuan untuk mengetahui hubungan tingkat pengetahuan dan sikap masyarakat dengan pelaksanaan Sanitasi Total Berbasis Masyarakat (STBM) di Wilayah Kerja Puskesmas Ratu Agung. Metode: Penelitian ini menggunakan desain cross sectional. Sampel pada penelitian ini adalah 96 responden. Data diperoleh dari hasil wawancara dan observasi tentang pengetahuan dan sikap terhadap pelaksanaan STBM. Hasil: sebanyak 66,7\% masyarakat memiliki pengetahuan baik dan 51,1\% memiliki sikap mendukung dalam pelaksanaan Sanitasi Total Berbasis Masyarakat (STBM) pilar pertama. dalam pelaksanaan Sanitasi Total Berbasis Masyarakat (STBM) pilar pertama. sebanyak $60 \%$ respondenpada kelompok kasus mempunyai riwayat pajanan pestisida dan kadar. Tingkat pengetahuan dan sikap secara signifikan berhubungan tindakan STBM pilar pertama. (p-value 0,006; 0,025). Simpulan: Kesimpulan penelitian ini adalah tingkat pengetahuan dan sikap berhubungan dengan tindakan STBM pilar pertama.
\end{abstract}

Kata Kunci: Pelaksanaan STBM, Pengetahuan, Sikap

\begin{abstract}
Title: Relations of Knowledge and Attitude With the First Community-Based Total Sanitation (STBM) Implementation In The Work Area Of The Wilayah Kerja UPTD Puskesmas Perawatan Ratu Agung Kelurahan Pematang Gubernur Kota Bengkulu. Background: The implementation of the STBM program starts from the first pillar, namely Stop BABs, which is the entrance to
\end{abstract}


total sanitation and is an attempt to break the chain of contamination of human waste from drinking, eating and other raw water. STBM is expected to change the behavior of community groups in an effort to improve their environmental sanitation conditions, so that Open Defecation Free (ODF) is achieved. behavioral determinants consist of predisposing factors (knowledge, action), enabling factors (socialization, facilities), reinforcement factors (family support and health workers). This study aims to determine the relationship between the level of knowledge and attitudes of the community with the implementation of Community Based Total Sanitation (STBM) in the Wilayah Kerja Puskesmas Ratu Agung. Method: This study used a cross sectional design. The sample in this study was 96 respondents. Data obtained from interviews and observations about knowledge and attitudes towards the implementation of STBM. Results: $66.7 \%$ of the community had good knowledge and $51.1 \%$ had a supportive attitude in the implementation of the first pillar of Community Based Total Sanitation (STBM). in the implementation of the first pillar Community Based Total Sanitation (STBM). $60 \%$ of respondents in the case group had a history of pesticide exposure and levels. The level of knowledge and attitude significantly related to the first pillar STBM action. (p-value 0,006; 0,025). Conclusion: The conclusion of this study is the level of knowledge and attitudes related to the first pillar STBM action.

\section{Keywords: Implementation of STBM, Knowledge, Attitude}

\section{PENDAHULUAN}

Permasalahan pembangunan sanitasi di Indonesia merupakan masalah tantangan sosial-budaya, salah satunya adalah perilaku penduduk yang terbiasa Buang Air Besar (BAB) disembarangan tempat, khususnya kebadan air yang juga digunakan untuk mencuci, mandi dan kebutuhan higienis lainnya. Berdasarkan Deklarasi Johannesburg yang dituangkan dalam Millenium Development Goals (MDGs) menetapkan pada tahun 2015 sepakat untuk menurunkan separuh proporsi penduduk dunia yang tidak memiliki akses sanitasi dasar yaitu jamban sehat dan harus mendapatkan akses sanitasi dasar (jamban) pada tahun 2025. Penetapan ini telah disepakati oleh Negara-negara didunia termasuk di Indonesia (Sari, 2011). Upaya pemerintah berdasarkan Keputusan Menteri Kesehatan RI Nomor 852/ Menkes/ SK/ IX/ 2008 yang disebut Sanitasi Total Berbasis Masyarakat (STBM) meliputi 5 pilar yaitu : Stop Buang Air Besar Sembarangan (Stop BAB Sembarangan), Cuci Tangan Pakai Sabun (CTPS), Pengamanan Makanan dan Minuman Rumah Tangga (PAM-RT), Pengelolaan Sampah Rumah Tangga (PSRT), Pengelolaan Air
Limbah Rumah Tangga (PSRT) (Ditjen PP dan PL 2008).

Pelaksanaan program STBM dimulai dari pilar pertama yaitu Stop BABs yang merupakan pintu masuk sanitasi total dan merupakan upaya memutuskan rantai kontaminasi kotoran manusia terhadap air baku minum, makan dan lainnya. STBM menggunakan pendekatan yang mengubah perilaku hygiene dan sanitasi melalui pemberdayaan masyarakat dengan cara pemicuan. Dengan metode pemicuan, STBM diharapkan dapat merubah perilaku kelompok masyarakat dalam upaya memperbaiki keadaan sanitasi lingkungan mereka, sehingga tercapai kondisi Open Defecation Free (ODF), pada suatu komunitas atau Desa.Suatu Desa dikatakan ODF jika 100\% penduduk desa tersebut mempunyai akses $\mathrm{BAB}$ di jamban sehat.

Menurut laporan STBM Nasional Capaian ODF nasional hingga tahun 2014 baru 44,17 \% dari semua daerah yang melaksanakan STBM. Provinsi Bengkulu yang telah melaksanakan program STBM sejak tahun 2013 baru mencapai 52,41\% sedangkan Kota Bengkulu yang terdiri dari 9 kecamatan, semuanya telah melaksanakan STBM dan baru mencapai 43,27 \%. 
Perilaku Buang Air Besar sembarangan (BABs) atau Open Defecation termasuk salah satu perilaku yang tidak sehat. BABs adalah suatu tindakan membuang kotoran atau tinja diladang, hutan, semak-semak, sungai, pantai atau area terbuka lainnya dan dibiarkan menyebar mengkontaminasi lingkungan, tanah, udara, dan air (Mukherjee, 2011). Sanitasi, personal higiene dan lingkungan yang buruk berkaitan dengan penularan beberapa penyakit infeksi yaitu diare, kolera, typhoid fever, dan paratyphoid fever, disentri, penyakit cacing tambang ascariasis, Hepatitis A dan E, penyakit kulit, trakhoma, malnutrisi dan penyakit yang berhubungan dengan malnutrisi (Cairncross, 2013). Prevalensi penyakit akibat sanitasi yang buruk di Indonesia adalah penyakit diare $72 \%$, cacingan $0,85 \%$, scabies $23 \%$, trakhoma 0,14 , hepatitis A $0,57 \%$, hepatitis E $0,02 \%$, dan malnutrisi 2,5\% sedangkan kasus kematian akibat sanitasi buruk adalah diare $46 \%$, cacingan $0,1 \%$, scabies $1,1 \%$, hepatitis A $1,4 \%$, dan hepatitis E $0,04 \%$ (WSP-EAP, 2008).

Penelitian Aulia Jayanti (2014) tentang "Evaluasi Pencapaian Program Sanitasi Total Berbasis Masyarakat (STBM) Pilar Pertama Di Wilayah Kerja Puskesmas Pungging Kabupaten Mojokerta Tahun 2012-2014" menyebutkan bahwa program Stop BABS masih belum menjadi prioritas masalah di wilayah kerja Puskesmas Pungging serta masyarakat belum berperan aktif dalam program ini karena status ekonomi yang rendah. Penelitian Akbar (2016) tentang hubungan faktor perilaku masyarakat dengan pelaksanaan STBM di Wonosobo tahun 2016 menyatakan bahwa faktor perilaku mempengaruhi pelaksanaan program STBM.

Berdasarkan data STBM Indonesia Kota Bengkulu memiliki 3 kecamatan dengan nilai BABs tertinggi pada tahun 2016 yaitu Kecamatan Teluk Segara 344 KK, Kecamatan Ratu Agung 311 KK, Kecamatan Kampung Melayu 210 KK sedangakan untuk Kecamatan Muara Bangkahulu sebesar 23 KK meski di kecamatan ini memiliki nilai BABs yang kecil tetapi dalam pelaksanaan
STBM Pilar pertama ini sebelum dan setelah dilakukan intervensi tidak memberikan kemajuan apapun dengan kata lain nilai BABs setiap tahunnya masih sama.

Berdasarkan wawancara awal dengan sanitarian UPTD Puskesmas Perawatan Ratu Agung yang dilakukan pada bulan Mei (2018) di UPTD Puskesmas Perawatan Ratu Agung terdapat beberapa permasalahan dalam pelaksanaan pilar pertama program STBM diantaranya kurangnya dukungan lintas sektor diantara pemangku kepentingan, sehingga partisipasi masyarakat dalam pelaksanaan pilar pertama STBM masih kurang, perekonomian masyarakat yang masih rendah serta pengetahuan dan sikap masyarakat yang masih kurang untuk wilayah Kelurahan Pematang Gubernur. Peneliti tertarik melakukan penelitian tentang hubungan tingkat pengetahuan dan sikap masyarakat dengan pelaksanaan Sanitasi Total Berbasis Masyarakat (STBM) Pilar pertama.

\section{METODE PENELITIAN}

Jenis penelitian ini adalah observasional analitik dengan pendekatan cross sectional dengan populasi masyarakat di Wilayah Kerja Puskesmas Perawatan Ratu Agung Kelurahan Pematang Gubernur sebanyak 2358 KK. Jumlah sampel dalam penelitian diperoleh berdasarkan perhitungan rumus sebesar 96 responden. Penelitian ini dilakukan dengan cara pengumpulan data wawancara menggunakan kuesioner dan pengamatan langsung tentang perilaku masyarakat Dalam Pelaksanaan Sanitasi Total Berbasis Masyarakat (STBM) pilar pertama kepada masyarakat di Wilayah Kerja UPTD Puskesmas Perawatan Ratu Agung Kota Bengkulu.

\section{HASIL PENELITIAN}

Tabel 1.1 Distribusi Frekuensi Tingkat Pengetahuan, Sikap dan Tindakan Masyarakat dalam Pelaksanaan Sanitasi Total Berbasis Masyarakat (STBM) Pilar Pertama di Wilayah Kerja Puskesmas 
Ratu Agung Tahun 2018

\begin{tabular}{|c|c|c|c|}
\hline No & Variabel & Frekuensi (F) & $\begin{array}{c}\text { Persentase } \\
(\%)\end{array}$ \\
\hline \multirow[t]{4}{*}{1} & $\begin{array}{c}\text { Tingkat } \\
\text { Pengetahuan }\end{array}$ & & \\
\hline & Kurang & 18 & 18,8 \\
\hline & Cukup & 14 & 14,5 \\
\hline & Baik & 64 & 66,7 \\
\hline \multirow[t]{3}{*}{2} & Sikap & & \\
\hline & Unfavorable & 47 & 48,9 \\
\hline & Favorable & 49 & 51,1 \\
\hline \multirow[t]{4}{*}{3} & Tindakan & & \\
\hline & Kurang & 12 & 12,5 \\
\hline & Cukup & 51 & 53,1 \\
\hline & Baik & 33 & 34,4 \\
\hline
\end{tabular}

Tabel 1.2. Hubungan antar variabel dalam penelitian

\begin{tabular}{|c|c|c|c|c|c|c|c|c|}
\hline \multirow{2}{*}{ No } & \multirow{2}{*}{$\begin{array}{c}\text { Variabel } \\
\text { Bebas }\end{array}$} & \multicolumn{6}{|c|}{ Tindakan STBM } & \multirow{2}{*}{$\begin{array}{c}P- \\
\text { Value }\end{array}$} \\
\hline & & \multicolumn{2}{|c|}{ Kurang } & \multicolumn{2}{|c|}{ Cukup } & \multicolumn{2}{|c|}{ Baik } & \\
\hline 1. & \multicolumn{8}{|c|}{ Tingkat Pengetahuan } \\
\hline & Kurang & 5 & $\begin{array}{c}27.8 \\
\%\end{array}$ & 10 & $\begin{array}{c}55.6 \\
\%\end{array}$ & 3 & $\begin{array}{c}16.7 \\
\%\end{array}$ & 0,006 \\
\hline & Cukup & 4 & $\begin{array}{c}28.6 \\
\%\end{array}$ & 8 & $\begin{array}{c}57.1 \\
\%\end{array}$ & 2 & $\begin{array}{c}14.3 \\
\%\end{array}$ & \\
\hline & Baik & 3 & $4.7 \%$ & 33 & $\begin{array}{c}51.6 \\
\%\end{array}$ & 28 & $\begin{array}{c}43.8 \\
\%\end{array}$ & \\
\hline 2. & \multicolumn{8}{|c|}{ Sikap } \\
\hline & $\begin{array}{c}\text { Unfavor- } \\
\text { able }\end{array}$ & 8 & \begin{tabular}{|c|}
17.0 \\
$\%$
\end{tabular} & 29 & $\begin{array}{c}61.7 \\
\%\end{array}$ & 10 & $\begin{array}{c}21.3 \\
\%\end{array}$ & 0,025 \\
\hline & $\begin{array}{c}\text { Favora- } \\
\text { ble }\end{array}$ & 4 & $8.2 \%$ & 22 & $\begin{array}{c}44.9 \\
\%\end{array}$ & 23 & $\begin{array}{c}46.9 \\
\%\end{array}$ & \\
\hline
\end{tabular}

\section{PEMBAHASAN}

\section{Hubungan antara Tingkat Pengetahuan dengan Tindakan STBM}

Hasil penelitian pada tabel 1.1 diketahui bahwa lebih dari setengah responden 64 orang $(66,7 \%)$ berpengetahuan baik dalam pelaksanaan Sanitasi Total Berbasis Masyarakat (STBM) pilar pertama. Tingkat pengetahuan berhubungan dengan tindakan STBM dengan nilai p-Value 0,006 $(<0,05)$ Hasil penelitian ini sejalan dengan penelitian Aulia Jayanti (2014) tingakat pendidikan mempengaruhi pola pikir dan daya cerna seseorang. Semakin tinggi informasi yang dapat diserap dan tingginya informasi yang diserap mempengaruhi pengetahuannya. Orang yang pendidikannya lebih tinggi lebih besar kepeduliannya terhadap masalah kesehatan.

Pengetahuan responden dalam Pelaksanaan Sanitasi Total Berbasis Masyarakat (STBM) pilar pertama adalah untuk mengetahui tentang seberapa besar masyarakat mengetahui Sanitasi Total Berbasis Masyarakat (STBM) pilar pertama stop buang air besar sembarangan. Dalam tingkatan pengetahuan terdiri dari beberapa tingkatan salah satu tingkatannya yang pertama adalah tahu. Tahu adalah sebagai suatu yang telah dipelajari sebelumnya, termasuk pengetahuan dalam tingakatan ini adalah mengingat kembali dari semua bahan yang telah dipelajari (Notoatmodjo, 2013).

Masyarakat di Kelurahan Pematang Gubernur berada pada tingkatan pengetahuan yang pertama yaitu tahu, dibuktikan dengan wawancara yang mengajukan beberapa pertanyaan dan masyarakat dapat menjawab pertanyaan yang diajukan.

Pengetahuan yang baik dapat dipengaruhi oleh beberapa faktor seperti sumber informasi, faktor pendidikan, dan faktor lingkungan. Semakin banyak orang mendapatkan informasi baik dari lingkungan keluarga, lingkungan tetangga, dari petugas kesehatan maupun media cetak akan mempengaruhi tingkat pengetahuan seseorang.

\section{Hubungan antara Sikap dengan Tindakan STBM}

Sikap responden dalam pelaksanaan Sanitasi Total Berbasis Masyarakat (STBM) pilar pertama telah cukup baik. Berdasarkan hasil penelitian pada tabel 1.1 menunjukan lebih dari setengah responden memiliki sikap yang favorable sebanyak 49 orang $(51,1 \%)$. Sikap masyarakat terhadap pelaksanaan STBM berhubungan dengan tindakan STBM dengan nilai $\mathrm{p}$-Value $0,025(<0,05)$.

Sikap dan kebiasaan masyarakat dalam 
pelaksanaan pilar pertama STBM ini sangatlah penting karena semakin tinggi masyarakat bersikap favorable maka semakin tinggi pula tingkat pelaksanaan STBM pilar pertama ini sehingga dengan sikap favorable ini dapat membantu dalam mensukseskan STBM pilar pertama dan dapat dideklarasikan ODF pada Kelurahan Pematang Gubernur. Hal ini diperkuat oleh penelitian Pane (2009) sikap mempengaruhi kebiasaan masyarakat buang air besar sembarangan.

Sikap merupakan reaksi atau respon seseorang yang masih tertutup terhadap suatu stimulus atau objek. Manifestasi sikap ini tidak dapat dilihat langsung, tetapi hanya dapat ditafsirkan terlebih dahulu dari perilaku yang tertutup. Sikap belum merupakan suatu tindakan atau aktivitas, akan tetapi merupakan predisposisi tindakan suatu perilaku. Sikap masih merupakan kesiapan untuk bereaksi terhadap objek dilingkungan tertentu sebagai penghayatan terhadap objek. Sikap mempunyai beberapa karakteristik yaitu selalu ada objeknya, biasanya bersifat evaluative, relative mantap, dapat dirubah. Sikap mempunayi 3 komponen pokok yaitu kepercayaan, kehidupan emosional, serta kecendrungan untuk bertindak. Ketiga komponen ini secara bersamaan membentuk sikap yang utuh. Penentuan sikap yang utuh ini pengetahuan berfikir, keyakinan dan emosi memegang peranan penting (Notoadmodjo, 2013).

Faktor yang mempengaruhi sikap antara lain : pengalaman pribadi merupakan dasar pembentukan sikap yang dapat meninggalkan kesan yang kuat, misalnya ketika ada masyarakat yang BAB sembarangan lalu dipengaruhi oleh tetangga untuk tidak BAB sembarangan. Hal ini merubah sikap masyarakat, pengaruh kebudayaan yaitu memberikan corak pengalaman individuindividu masyarakat, media masa berpengaruh terhadap sikap konsumennya, dari lembaga pendidikan dan lembaga agama dapat mempengaruhi sikap seseorang dalam bertindak dan faktor emosional yaitu faktor yang didasari oleh emosi seseorang dalam penentuan sikap dan pertahanan ego.

\section{KESIMPULAN}

Hasil penelitian dapat disimpulkan bahwa sebagian besar responden $(66,7 \%)$ masyarakat memiliki pengetahuan baik dan sebagian besar $(51,1 \%)$ memiliki sikap mendukung dalam pelaksanaan Sanitasi Total Berbasis Masyarakat (STBM) pilar pertama. Ada hubungan antara tingkat pengetahuan dan sikap dengan tindakan (p-value 0,006; 0,025) dalam pelaksanaan Sanitasi Total Berbasis Masyarakat (STBM) pilar pertama.

\section{SARAN}

Bagi tokoh masyarakat dan kader kesehatann lingkungan untuk memberikan informasi tentang STBM melalui berbagai media sehiingga dapat meningkatkan pengetahuan dan sikap masyarakat untuk mendukung upaya pelaksanaan STBM di Kelurahan Pematang Gubernur.

\section{DAFTAR PUSTAKA}

Akbar. 2015. Faktor-faktor yang berhubungan pengunaan jamban keluarga di desa Pegagan Julu III Kecamatan Sumbul Kabupaten Dairi tahun 2015.

Aulia.Jayanti. 2014.Evaluasi pencapaian program sanitasi total berbasis masyarakat pilar pertama diwilayah kerja puskesmas pungging kabupaten mojokerto tahun 2012-2014.

Cairncross, S., Caroline, H., Sophie, B., Kristof, B., Val, C., Isaac CH Fung., \& Wolf-Peter, S. (2013). Water, Sanitiation and Hyigiene for The Prevention of Diarrhoea. Int.J. Epidemiol, 39 (Suppl 1): 193-205.

Depkes RI. 2008. Strategi Nasional Sanitasi Total Berbasis Masyarakat. Jakarta.

Erickso sidjabat. 2015. Partisipasi masyarakat desa dalam implementasi strategi nasional sanitasi total berbasis masyarakat di kabupaten grobongan.

Kemenkes RI. 2011.Pedoman Pelaksanaan Sanitasi Total Berbasis Masyarakat. 
Jakarta.

Mukherje, 2014.Pengetahuan Masyarakat Tentang Pengelolaan Sanitasi Berbasis Masyarakat.Tesis.Universitas Diponegoro Semarang.

Notoatmodjo, Soekidjo. 2013. Pendidikan Dan Perilaku Kesehatan. Rineka.Cipta. Jakarta.

Pane.2009. Hubungan Karakteristik Individu dan Kepemilikan Jamban Keluarga Dengan Tindakan Buang Air Besar Sembarangan (BABS) di Desa Sosor Tolong Kecamatan Doloksanggul Kabupaten Humbang Hasundutan Tahun 2016.

Sari, Utami. 2011. Faktor-faktor yang Berhubungan dengan Kebiasaan Cuci Tangan Pakai Sabun pada Masyarakat di Desa Cikoneng Kecamatan Ganeas Kabupaten Sumedang 2010. [tesis]. Fakultas Kesehatan Masyarakat Universitas Indonesia.Depok.

WHO/UNICEF. 2011 Progresss on Sanitation and Drinking Water, 2011 Update.Gevena 